\title{
Gendered Spaces in the City: Critical Topography in Geography Education
}

\author{
Christiane Hintermann and Herbert Pichler \\ Department of Geography and Regional Research, University of Vienna, Austria · \\ christiane.hintermann@univie.ac.at
}

Full paper double blind review

\begin{abstract}
Street names in city maps may be interpreted as traces of memory practices and politics, and can clearly be identified as the products of hegemonic norms and values of a given time and place. In the following article we describe a project-oriented teaching unit for secondary school students. In the course of the project, students are instructed to research either their school or residential neighborhoods, looking at the persons and events commemorated and written into the city. These toponymic inscriptions can be analyzed by studying the naming practice of streets and squares. Which people and events are remembered and which are forgotten? Do these events and people indicate processes of social inclusion, exclusion, marginalization, and discrimination? Investigating naming practices will be the starting point for the students to develop their own naming suggestions, as well as encouraging their active engagement in further negotiation processes regarding naming practices in their towns and villages. The teaching proposal is based on the idea of a geography teaching that educates politically, and meets the requirements of a critical topography approach (VIELHABER 2012). Students will also gain experience in aspects of a critical map reading competence (GRYL 2009) and the work can also be situated within the context of critical place-name studies (ROSE-REDWOOD 2009).
\end{abstract}

\section{Topography and Maps in Geography Education: Historical Relicts or Sustainable Concepts?}

Experts in the fields of subject didactics and geography education seem to agree that geo media and other cartographic representations should continue to be a part of geography education in schools (DGFG 2014). This is the point, however, where the consensus ends. One contentious issue is how such learning outcomes can be assessed, something that might be the result of educational approaches seemingly only using maps, an apparently objective source of information (cf. DAUM 2011). Another perennial issue in how geography is taught in Germany and Austria is the discussion of the role and importance of isolated topography learning, a concept, which some critics have argued, shows fundamental deficits. One of the problems is the simplified interpretation of the concept itself in the school context (VIELHABER 2007, 2012). From a critical and constructivist point of view, topography cannot be interpreted as the isolated teaching of 'what is where?' (VIELHABER 2012, 91). To reduce topography to a mere localization, without deconstructing the meaning and origin of 
names and locations would not only ignore the political content and agenda connected to topographical terms and their transgenerational transmission in school, but it would also neglect the important role of topography as a practice "which describes boundaries, including property relations, and thereby objectifies them, rationalizes them and makes them seem like objects of nature through the legitimizing tropes of the discourse of science" (DUNCAN \& LEY 1993, 1). Teaching topography as the sheer enumeration of place names will also immediately evoke criticism for being arbitrary. (DOBLER \& PICHLER 2004, VIELHABER 2007, GRYL 2009). Simply listing a catalogue of topographical terms, which might be expanded ad infinitum, neither contributes to the development of any specific capability to act, nor to the development of any specific skills, as critics further argue (VIELHABER 2012, 91).

A "critical topography" concept on the other hand not only addresses the significance of names and terms, but also makes it clear that particular topographical orientation patterns which frame our individual world view are (re)produced in a heteronomous way (VIELHABER 2012, 101). Didactic considerations which take the idea that maps and geo media are a construction as a starting point for learning and cognition processes can equip students to "rethink mapping as the production of space, geography, place and territory, as well as the political identities people have who inhabit and make up these spaces" (CRAMPTON \& KRYGIER 2006, 15 with reference to PICKLES). This is especially evident in cases where students create subjective maps symbolizing their own experiences of the world (DOBLER \& PICHLER 2004, DAUM 2011, ElWOOD \& MitChell 2013). This constitutes a possibility for students to step outside their passive role as users and consumers of geo media. Instead, they are empowered to visualize and communicate their own interpretations and appropriations of places and space in the sense of a spatial citizenship (GRYL \& JEKEL 2012).

Looking at the effects of mapping, generalization, or specific cartographical representations, and the underlying motives, will help students to develop a critical map reading competence (GRYL 2009). Critical "topography-doing" also makes it necessary to recognize the effects of topographical naming, as well as regionalization or demarcation processes on all scales, from the local to the global level. Such a critical topography linked to political and citizenship education comes as close as possible to what the "competencies" in geography education might be (PICHLER 2013).

These brief and basic didactic considerations form the basis for the following draft of a project-oriented teaching unit for secondary education.

\section{Case Study: Tracking Traces in City Maps}

\subsection{Introduction and Aims}

How can we familiarize students with the idea that cities - as well as spaces in general - are a construction? Urban development or urban expansion programs might be good examples, particularly where there is the possibility of participative planning. The practice of naming streets can be a useful starting point for exploratory learning, but also for civic learning. The names of streets and places are the outcome of specific negotiation processes and do not happen accidentally (YEOH 1996; NEMEC 2008). On the contrary, critical place-name studies have shown that place/street naming is to be interpreted as a "mechanism for natu- 
ralizing hegemonic power structures", and can also be connected to the "production of racialized, gendered, and commodified landscapes" (ROSE-REDWOOD et al 2009, 457). Some studies have also suggested that toponoymic inscriptions can be considered "as a form of 'social capital' in the definition of BOURDIEU (1986) (ibid.).

Printed and digital city maps, together with other geo media, are almost exclusively used as orientation aids in real space, and interpreted as reality in geography education. What is very often missing is a critical and constructivist discussion of geo media and a critical approach towards topography (GRYL 2009, VIELHABER 2012). The following lesson plan considers two issues as starting points for a critical study of toponymic inscriptions: the gender gap, which is obvious when it comes to the naming of streets and public space (cf. background information below), and problematic street names commemorating people with controversial biographies, such as members of the National Socialist Party.

The educational objective of the critical analysis of symbolic representations in public space (street names in the case study) is to enable secondary school students to perceive the constructedness and the processual character of places and spaces, and how they are named. Students will be able to observe the symbolic meaning of spaces and learn to track and read traces of societal power relations in space ("Who has the right to space?" MiTCHELL 2004). The project consists of two main parts: In the first part students deconstruct political decision-making processes (the procedure behind naming spaces) and the underlying social discourse of values and norms that are reflected in the selection criteria for street names. In a second step, students are actively involved in the social construction of space by engaging in the public and political negotiation processes on the question of who and what should be written into the city in the future. The project ideally ends with a public presentation outside school, or an intervention in public space itself, encouraging further debate on the topic within the community.

\subsection{Methodological Approach: Tracking Traces on the City Map}

The methodological realization in the classroom builds on the sign-trace-paradigm, as developed by the German geographer Gerhard Hard in the 1980s and 1990s (e.g. 1995), although it does not adhere to the method in the strictest sense. Socially generated signs (street names) are interpreted as traces that can be followed (PICHLER 2012) and also read in city maps.

\subsection{Preparation}

This suggested teaching unit consists of at least four one-hour lessons. The time required depends greatly on the size of the case study area. The definition of the case study area is of central importance, not only for time management, but also for other pragmatic considerations, such as the skills and capabilities of the students, as well as their motivation. The study area would ideally be the school or residential environment of the students. This obvious relation to their daily lives might prove a motivating factor. The teacher can define a proposal for one large study area or several smaller research sites (e.g. historical city center, urban expansion zone, etc.) if the work is organized collaboratively. Provided that there is enough time, this can also be done together with the students. Other practical issues to be considered at the preparation stage of such a project are the provision of sufficient city 
maps (digital versions may help with the analysis and graphical representation of the findings) a consideration of the size and number of working groups, and a potential blocking of the lessons.

\subsection{Implementation}

When introducing the teaching unit, students are already addressed and involved in their constructivist role: they are asked to gather proposals for street naming (see Material 1 below). It might be possible that the gender bias in the practice of street naming already becomes evident at this early stage of the project. A subsequent discussion and reflection of the suggestions are supported by Material 2 and Material 3. The following group work is the main phase of the explorative learning unit, and can be divided into three steps (Material 4):

1. The first step is the analysis of naming practices. Each group is responsible for one section of the study area. Prior to the actual analysis, students are asked to think of categories into which the street names might be divided. In order to foster learning, each group can form their own categories. However, to allow for comparisons - if this is what the teacher and/or the class are interested in - the groups will have to agree on common categories. Creating tables is one possible way to document the findings, producing graphic or cartographic illustrations is another. If the research makes it necessary to conduct expert interviews, for instance with politicians or people from the local council, the interview requests should be coordinated between the groups. To prepare the subsequent analytical work, students are asked to come up with further research questions.

2. In the next step students delve deeper into the topic. Material 4 (below) offers two alternative research questions regarding the gender gap on the one hand, and potential renaming processes on the other. It is of course possible to develop and pursue additional research questions based on the material.

3. In the final step, students develop suggestions for future street naming in their town or village. This exercise supports political engagement and education in the teaching process. It becomes obvious that the "project" has effects beyond the classroom, exceeding the documentation of social practices and the analysis of observed social deficits or discrimination. The learners are encouraged to articulate their own concerns publicly, and to actively engage in the political processes of street naming, thereby fostering political subject formation (cf. ELWOOD \& MITCHELL 2013). The findings should be presented publicly. Interventions in public space - perhaps in combination with artwork might complement more conventional forms of presentation and the use of print and digital media. Inequalities, social exclusion, and marginalization processes in the naming practice can for instance be expressed with the help of the Theater of the Oppressed theatrical form, developed by Augusto Boal (1979). 


\subsection{Reflection}

The project-based teaching unit ends with a phase of reflection; central findings are collected and potential factors of success (or failure) defined. The following guiding questions can inspire the reflection process:

- What observations and findings can be drawn from the cooperation within the groups?

- What were the perceptions of street naming at the beginning of the project? What has changed in the course of the analysis?

- What insights have been gained into geo media and maps as constructions?

- What was learned by developing categories for the analysis?

- Which forms of technical support could be used for the analysis and the representation of the findings? Which limits were met? How might these limits be overcome in future studies?

- What were the effects of the chosen methods of public presentation? Which alternatives could be used?

\subsection{Transfer and Possible Variations}

If not enough time is available, it is possible to carry out a smaller model of this teaching proposal. A combination of Step 1 and Alternative 1 of Step 2 allows for a focus on the gender bias in the naming practice from the very beginning. Another possible alternative is a comparative study on street names from city maps of different cities on a national, European, or global scale. Such an approach would, however, require more preparation on behalf of the teacher.

\section{Background Information: City Maps as Sites of Memory or: What is inscribed into the City?}

Until the end of the $18^{\text {th }}$ century, the main purpose of street names in Europe was for orientation (STACHEL 2007, 32) using the names of fields, signposts, or the designation of city quarters according to crafts and trade. Since the French Revolution, however, public space has become more and more politicized; the naming and renaming of streets and squares was established as an instrument of power, dominance, and remembrance (MILO 1986), and changes to street names became "an obligatory accompaniment to political changes" (HEBBERT 2005, 582). National and local narratives were - and remain - imprinted and localized in cities and the urban network of roads. Street names are not simply a useful tool with which to navigate a city, but have other functions too. They are, as CSÁKY put it: "of special importance when it comes to the construction of a collective city identity" (2001, 263). Street naming can thus be interpreted as part of the politics of remembrance of a city, and is one way of symbolically appropriating public space.

Names on maps can therefore be read as part of the official memory of a city or a nation, acting as evidence of social norms and values at a given time. The practice of assigning 
names to streets and squares is a highly political process and a way of symbolically recognising individuals or groups of people. This also means that city maps can be perceived as a documentation of social and political power relations. The renaming of various squares in Austrian district and provincial capitals to Südtiroler Platz (South Tyrol Square) after the occupation of South Tyrol by Italy and the Treaty of Saint Germain (1919) is only one example of this symbolic policy. A more recent example might be the renaming processes for streets in Eastern Europe after the fall of communism. The important question is which person or event is remembered and therewith recognized, and which histories and social groups, as well as whose histories are excluded or marginalized?

Generally speaking, women or members of minority groups are still either under-represented or entirely forgotten. In her work on Los Angeles, Dolores HAYDEN, for instance, has shown that the history of women and ethnic minorities is hardly remembered at all in the urban landscape (1995). In Vienna, only about $10 \%$ of all street names commemorating a person are named after a woman (RATHKOLB et al. 2013, 24; NEMEC 2008). In the provincial capital of Klagenfurt this male dominance is even more pronounced, at $95 \%$ (VIELHABER 2007, 17f). However, it is not only the quantitative under-representation of women that is striking, but also a qualitative discrimination. Street names commemorating women are rarely found in (historic) city centers, instead they tend to be at the (younger) city margins (VIELHABER 2007, NEMEC 2008). It is also obvious that important city squares and central roads are predominantly named after men; female persons are more frequently commemorated with small roads, side alleys, and dead end roads (ibid.). Tentative first attempts to change the naming practice in favor of women and contribute to a more equal representation of men and women in public space have been initiated more recently in some cities.

More public attention is given to the discussion on the renaming of streets and squares commemorating people with controversial aspects in their biographies, especially in Austria and Germany, than is given to the gender bias. Vienna was one of the first cities to authorize an independent historical commission to investigate the city's street names. The final report of the project was submitted in 2013 and identifies 159 problematic names, out of a total of 6600 street names (roughly 4400 of which commemorate a person) (RATHKOLB et al. 2013, 13f). Many of the problematic cases are associated with the National Socialist period in Austria. The members of the historical commission also developed suggestions on how to deal with these street names. As well as the more obvious proposal of simply renaming some of the streets, the commission encouraged city representatives to add additional information plaques addressing positive and negative aspects of the biography of the person in question. Another suggestion was to support artistic interventions in public space to allow room for critical perspectives to rise (ibid., 13). One practical result of the work done by the commission was the renaming of the Dr.-Karl-Lueger-Ring, a section of Vienna's Ringstraße where Vienna University is situated, into Universitätsring. Karl Lueger was a mayor in Vienna at the beginning of the $20^{\text {th }}$ century, leader and cofounder of the Austrian Christian Social Party, but also infamous for his anti-Semitic rhetoric and policy. 


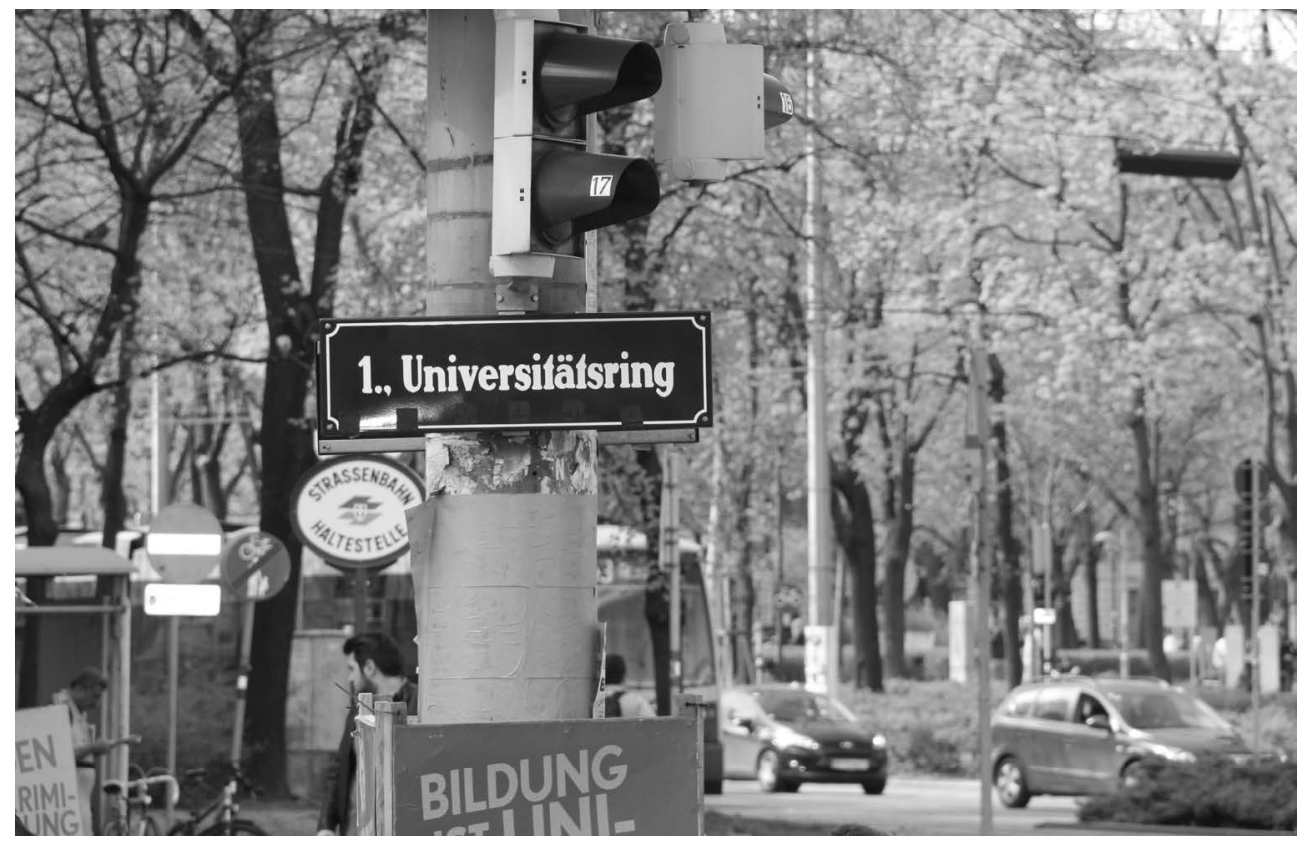

Fig. 1: The recently renamed Dr. Karl-Lueger-Ring in Vienna, a section of Vienna's Ringstraße (picture: Christiane Hintermann)

However, there are still other spaces in the city center named after him, such as the $D r$. Karl-Lueger-Square with a monumental Lueger statue ensemble.

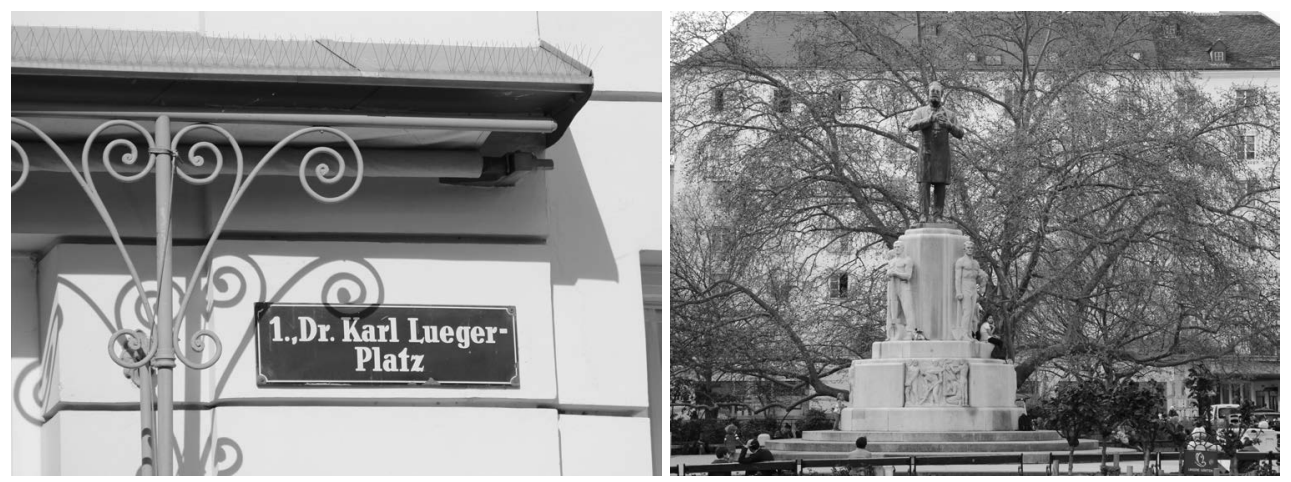

Fig. 2: The Dr. Karl-Lueger-Square in Vienna's city center and the Lueger-monument on the very same place (pictures: Christiane Hintermann) 


\section{Research Assignments and Material}

This section suggests research assignments and research questions and provides material useful for when teaching the unit described.

\subsection{Material 1: Introduction}

Streets and squares are frequently named after (deceased) persons who have rendered outstanding service to the city or nation, or whose actions and lives are recognized as memorable in general.

Which people should be commemorated by having a public street or a square named after them? Specify at least three people who deserve to be honored in this way in your hometown or neighborhood and why. Briefly argue your suggestions.

\subsection{Material 2: Implementation}

- Analyze the lists of names in class and consider whether men and women have been commemorated in equal measure. Discuss the findings.

- Estimate the ratio of male to female street names in your hometown.

- Formulate a theory on how this ratio of male to female distribution might have come to be.

\subsection{Material 3: Gender-gap in the Practice of Street Naming}

Results of an analysis undertaken by university students in the provincial capital Klagenfurt (Carinthia/Austria)

At the time of the study, 1364 official street names could be identified in Klagenfurt, 482 of them relating to individuals. A gender specific differentiation of the latter shows a proportion of $95.6 \%$ male codes (461 names). The male population in the city amounts to $46 \%$, and so the practice of allocating topographical codes should be challenged. [...] The gender imbalanced distribution is shown convincingly with maps that differentiate between streets with male and streets with female names. The maps also reveal another inequality. There are only four streets commemorating women in the higher-ranking inner parts of the city with a combined length of 600 meters. In contrast, the number of streets named after male personalities amounts to 62 , some of them with an individual length of more than 1000 meters. [...] Not a single road named after women comes close to a kilometer, whereas a significant share of the "male streets" exceed this. In conclusion, a last issue shall be added to indicate how strongly the status quo influences and reinforces the awareness and perception of people. Interviews with inhabitants have shown that male street names are much more strongly anchored in the "mental maps" of the interviewees, whereas roads with a female name are hardly remembered. [Translated and shortened after VIELHABER 2007, 19f] 


\section{Excerpt from the report of the historical commission on the clearing of street names in} Vienna (2013)

In order to reduce the continued imbalance regarding the naming of streets and squares after individuals, emphasis is put on the stronger visibility of women in public space. Only $10 \%$ of street names commemorate women, $90 \%$ men. The current naming practice of the City of Vienna already shows a change in pattern. In the year 2012, more newly named streets were named after women than men for the first time. The reason for this was a blocked naming of streets after women in the urban expansion area Seestadt Aspern [Lake City Aspern]. Shortly before the editorial deadline of this report, the municipal council enacted a new criteria checklist operative for new street naming. A proposal by the RedGreen coalition city council concerning this matter was approved unanimously. In the future, women shall be considered more often when naming streets. Other criteria mentioned include conciseness, distinctness, and a relationship to Vienna. Renaming shall continue to be an exception to the rule. Another issue that shall be considered in future street naming is the fact that Vienna is also a city of immigration. [Translated, shortened and slightly changed after RATHKOLB et al. 2013, 21f]

\section{Tracking traces in Graz (2014)}

In Graz [the provincial capital of the Austrian province Styria] only roughly 40 streets commemorate women, corresponding to $2.5 \%$ of all street names. Most of them can be found in newly built areas at the periphery of the city. "Nine of the 40 are dead-end roads, eight are private roads, and six are only approachable by bike or on foot", specifies Ina Mastnak, who looked for traces in the frame of the project "Lost Space?".

\subsection{Material 4: Research Assignment: Tracking Traces in the City Map}

Define the scope of the study area (whole city area, city districts, etc.) in your class/group, and agree upon the division of the space between the working groups. Steps 1 and 3 are carried out in a plenary session; a division of work is also possible. In the second step, students can either work on one of the two suggested research questions or develop their own line of questioning.

\subsubsection{Step 1: Deconstruction of the Naming Practices Regarding Urban Public Roads and Spaces}

\section{Research question: What is written into the city?}

- Examine the street and square names in your research area. If possible, try to identify patterns.

- Create categories to sort the street names into. If you have problems accurately assigning individual street names, consider web-based inquiries or contact representatives of the appropriate city department or political decision makers.

- Document the position of the different categories of street names in cartographic media (analog or digital).

1 Translated and cited after http://kurier.at/thema/weltfrauentag/wie-wiens-strassen-weiblicherwerden-sollen/54.735.422 [accessed 31/3/2015] 
- Investigate the historical and current naming practices and regulations in the relevant department of the municipal council. Who has the power to decide? According to what criteria? Draw a flow chart of the process of street naming.

- Develop further research questions of your own. (E.g. are their specific groups of people who are not visible at all in the street names of the city and the city maps? What remains hidden? Who is forgotten?)

- Document your findings in a report; include graphic and cartographic illustrations and visualizations too.

\subsubsection{Step 2}

Alternative 1: Deconstruction and visualization of the gender gap in the naming of urban public roads

\section{Research question: How are men and women represented on the city map?}

- Concentrate your analysis of the street names referring to individuals, and especially on the proportion of male and female names. If it is not possible to explicitly assign particular street names, a web-based inquiry or interviews with representatives of the appropriate city department or political decision makers may help.

- Document the position of the different categories of street names using cartographic media (analog or digital) and visualize female and male names.

- Describe conclusions drawn from the gender-specific analysis regarding the location of the person-related roads (center, periphery), their length, and the hierarchy of the streets (main road, by-road, etc.). Create your own research questions to investigate the city in relation to the gender aspect.

- Document the results of your analysis; include your research findings regarding the past and current naming procedure (see Step 1). Develop guidelines for the future political practice of street naming in your municipality (in your research area).

- Summarize your findings in a report; include the graphical and cartographical illustrations and visualizations.

Alternative 2: “Vergangenheitsbewältigung" (coming to terms with the past) of the city map (possibility for interdisciplinary work with the subject history)

Research question: Are there street names commemorating people with controversial biographies in the city? How can such toponymic cases be dealt with?

- Research whether there are any publications or documents on problematic cases of the public commemoration of people with controversial biographies in the city map (webbased research, research in the online archives of local papers, expert interviews with historians).

- Discuss different possibilities of dealing with problematic street names; discuss the advantages and disadvantages of the different approaches.

- Document an example of the media discussion of a contentious street name.

- Develop a detailed report on how to approach a documented example of a problematic street name und present your recommendations to those politically responsible for such decision-making. 


\subsubsection{Step 3: Construction: Rewrite the City!}

Which persons or historical events should be commemorated in the city in the future? Which street names ought to be renamed? Do not surrender the power of naming streets and squares in your city to others! Actively participate in the discussion and the naming processes regarding public space. Prepare reasonable suggestions for the naming and renaming of streets and present them to those responsible. Integrate the results of the project, current problems, shortcomings and inequalities concerning the naming practices, as well as the current socio-political discourse on the marginalization of social groups into your proposals. Support your request with the help of your research findings as well as by means of (carto)graphical visualization.

As a next step, consider how you might effectively present your results and concerns in public. Choose adequate methods to show your concerns.

\section{Ideas for a publicly-oriented communication of the research findings:}

- Public presentation of the results with the participation of local decision makers.

- Forward the project findings and your requests to the city government and the municipal council.

- Publication of the results and requests in print and digital local media as well as in social media.

- Discuss and design possible interventions in the public space in order to highlight your findings, optionally also through artistic methods.

\section{References}

Autengruber, P. (2004), Lexikon der Wiener Straßennamen. Bedeutung. Herkunft. Frühere Bezeichnungen. 5th Edition. Pichler, Wien.

BOAL, A. (1979), Theater of the Oppressed. Pluto, London.

Bourdieu, P. (1986), The forms of capital. In: Richardson, J. (Ed.), Handbook of Theory and Research for the Sociology of Education. Greenwood, New York, 241-258.

Crampton, J. M. \& KRYgier, J. (2006), An Introduction to Critical Cartography. ACME, $4(1), 11-33$.

CsÁKY, M. (2001), Das Gedächtnis der Städte. Kulturelle Verflechtungen - Wien und die urbanen Milieus in Zentraleuropa. Böhlau, Wien.

DAUM, E. \& HASSE, J. (Eds.) (2011), Subjektive Kartographie. Beispiele und sozialräumliche Praxis. Oldenburg.

DGFD (2014), Bildungsstandards für die Mittleren Schulen im Fach Geographie mit Aufgabenbeispielen. 8th updated Edition. Bonn.

DoBler, K. \& PiChleR, H. (2004), Erlebte Topographie. Türen öffnen für ein kreatives Raumverständnis. In: VIELHABER, C. (Ed.), Fachdidaktik alternativ - innovativ. Acht Impulse um (Schul-)Geographie und ihre Fachdidaktik neu zu denken. Materialien zur Didaktik der Geographie und Wirtschaftskunde. Institut für Geographie der Universität Wien. Vol. 17, 35-48.

DunCAN, J. \& LEY, D. (1993), Introduction. Representing the place of culture. In: DunCAN, J. \& LEY, D. (Eds.), Place - Culture - Representation. Routledge, London, 1-21. 
Elwood, M. \& Mitchell, K. (2013), Another Politics is Possible: Neogeographies, Visual Spatial Tactics, and Political Formation. Cartographica, 48 (4), 275-292.

GRYL, I. (2009), Kartenlesekompetenz. Ein Beitrag zum konstruktivistischen Geographieunterricht. Materialien zur Didaktik der Geographie und Wirtschaftskunde. Institut für Geographie der Universität Wien, Vol. 22.

GRYL, I. \& JEKEL T. (2012), Re-centring Geoinformation in Secondary Education: Toward a Spatial Citizenship Approach. Cartographica, 47 (1), 18-28.

HARD, G. (1995), Spuren und Spurenleser: zur Theorie und Ästhetik des Spurenlesens in der Vegetation und anderswo. Osnabrücker Studien zur Geographie, Vol. 16.

HAYDEN, D. (1995), The Power of Place. Urban Landscapes as Public History. MIT Press, Cambridge \& London.

HeBbert, M. (2005), The street as locus of collective memory. Environment and Planning D: Society and Space, 23, 581-596.

Milo, D. (1986), Le nom des rues. In: NorA, P. (Ed.), Lex Lieux de Mémoire: La Nation, Vol. 2. Gallimard, Paris, 283-322.

Mitchell, D. (2004), The Right to the City: Social Justice and the Fight for Public Space. Blackwell, Oxford.

NEMEC, B. (2008), Straßenumbenennungen in Wien als Medien von Vergangenheitspolitik. 1910-2010. Mit besonderer Berücksichtigung der Gender-Problematik. Diplomarbeit, Universität Wien.

PICHLER, H. (2012), Migrationen und ethnische Ökonomien finden Stadt. Trittsteine für projektorientierten Unterricht vor Ort. In: DABRINGER, M. \& TRUPP, A. (Eds.), Wirtschaften mit Migrationshintergrund. Zur soziokulturellen Bedeutung ethnischer Ökonomien in urbanen Räumen. Studien Verlag, 107-119.

PICHLER, H. (2013), Kritische Kompetenzorientierung konkret - Fachdidaktische Leitgedanken für die Umsetzung einer kritisch gewendeten Kompetenzorientierung im GWUnterricht und für die Erstellung von Aufgaben für die kompetenzorientierte Reife- und (Diplom-) Prüfung. GW-Unterricht, 130, 15-22.

Rathkolb, O. Autengruber, P., Nemec, B. \& Weninger, F. (2013), Forschungsprojektendbericht Straßennamen Wiens seit 1860 als „Politische Erinnerungsorte“. Erstellt im Auftrag der Kulturabteilung der Stadt Wien (MA 7).

Rose-Redwood, R., Alderman, D. \& AzARYAHU, M. (2010), Geographies of toponymic inscription: new directions in critical place-name studies. Progress in Human Geography, 34 (4), 453-470.

STACHEL, P. (2007), Stadtpläne als politische Zeichensysteme. Symbolische Einschreibungen in den öffentlichen Raum. In: JAWORSKI, R. \& STACHEL, P. (Eds.), Die Besetzung des öffentlichen Raumes. Politische Plätze, Denkmäler und Straßennamen im europäischen Vergleich. Frank \& Timme, Leipzig, 13-60.

VIELHABER, C. (2007), Kritische Topographie - Was soll das sein? Gedanken, Perspektiven und Versuch einer Umsetzung. GW-Unterricht, 108, 11-20.

VIELHABER, C. (2012), Kritische Topographie - Gibt's die? Mitteilungen der Österreichischen Geographischen Gesellschaft, 154, 89-106.

YEOH, B. S. A. (1996), Street-naming and nation-building: toponymic inscriptions of nationhood in Singapore. Area, 28 (3), 298-307. 